\title{
Citra Perempuan Pada Produk Rokok di Era Tahun 1930-1950
}

\author{
Ahmad Muhaimin, Sisca Shamannia \\ Fakultas Ilmu Sosial dan Ilmu Politik Universitas Islam Negeri Raden Fatah Palembang \\ Email: siscasahmannia@gmail.com
}

\begin{abstract}
Analysing cigarette advertisements that existed in ancient times, is an interesting study. Not only because the study is a study of the past, but the adverts in which make the figure of a woman become one of the most important icons in the process of marketing cigarette products. Starting from exposing women's bodies, to the brands of cigarettes taken from women's names. Photos or pictures contained therein have meaning and signs on the sheet, so this is the main object seen by a reader in interpreting the photo. it means that each photo has important points to study. Research entitled: Image of Women in Cigarette Products in the 1930-1950 Era in Indonesia. Aims to read the meaning that is written in it by describing the socio-cultural situation, maybe the politics around it or the ideological meanings contained therein. The methodology used in this research is descriptive, with a qualitative approach. The meaning referred to in this study is the meaning based on analysis using Roland Batrhes's Theory of Semiotics which is the meaning of denotation, connotation and myth. The meanings will appear on every sign that is captured by the reader through the five senses that are interpreted based on knowledge, and also the existing history of this study focuses on the past. The number of photos to be analyzed consists of three photos, which will be divided into several sections. With one photo to be broken down into objects, it aims to make it easier to read the meanings and meanings of denotations, the myths that are in it. As well as knowing the intention of the cigarette ad image maker, so that it can contain the formation of the image formed. There are 3 images formed from the results of a study of the advertisement photos of cigarette products, these are: image frames, imagery of fusion, and social imagery.
\end{abstract}

Keywords: cigarette advertisement, photos, women, meanings

\begin{abstract}
Abstrak
Mengkaji iklan rokok yang ada pada zaman dahulu, adalah sebuah kajian menarik. Bukan hanya karena kajian tersebut sebagai kajian masa lampau, tetapi iklan yang di dalamnya menjadikan sosok seorang perempuan menjadi salah satu ikon yang sangat penting dalam proses pemasaran produk rokok. Mulai dari mengekspos tubuh perempuan, sampai pada merk rokok yang di ambil dari nama perempuan. Foto atau gambar yang terdapat didalamnya memiliki makna dan tanda-tanda didalam lembaran, sehingga hal ini menjadi objek utama yang dilihat oleh seorang pembaca dalam
\end{abstract}


memaknai foto tersebut. artinya setiap foto memiliki poin yang penting untuk dikaji. Penelitian yang berjudul : Citra Perempuan Pada Produk Rokok Pada Era Tahun 1930-1950 Di Indonesia. Bertujuan untuk membaca makna yang tersurat di dalamnya dengan menggambarkan situasi sosial budaya, mungkin juga politik yang ada disekelilingnya atau makna ideologi yang terkandung di dalamnya. Metodologi yang digunakan dalam penelitian ini adalah deskriptif, dengan pendekatan kualitatif. Makna yang dimaksud dalam penelitian ini adalah makna berdasarkan analisa menngunakan Teori Semiotika menurut Roland Batrhes yaitu makna denotasi, konotasi dan mitos. Makna-makna akan muncul pada setiap tanda yang ditangkap oleh pembaca melalui panca indera yang dimaknai berdasarkan pengetahuan, dan juga sejarah yang ada mengingkat kajian ini berfokus pada masa lampau. Jumlah foto yang akan dianalisis ini berjumlah tiga foto, yang akan dibagi dalam beberapa bagian. Dengan satu foto akan dipecah menjadi perobjek, hal ini bertujuan untuk memudahkan dalam membaca pemaknaan makna dan tanda denotasi-kontasi, mitos yang ada didalamnya. Serta mengetahui maksud pembuat gambar iklan rokok tersebut, sehingga bisa memuat pembentukan citra yang terbentuk. Ada 3 citra yang terebentuk dari hasil penelitian terhadap foto-foto iklan produk rokok ini ialah : citra pigura, citra peraduan, serta citra pergaulan.

Kata kunci : iklan rokok, foto, perempuan, makna

\section{PENDAHULUAN}

Kesadaran akan potensi perempuan sebagai objek yang digunakan dalam strategi pemasaran telah dimiliki oleh pelaku pemasaran sejak dulu. Melalui proses pengolahan dan pengaturan komposisi dengan cara yang sederhana, beberapa media promosi berupa etiket, maupun iklan yang dibuat pada awal perkembangan industri rokok menunjukkan keterkaitannya dengan aspek sosial kebudayaan

Perempuan dan iklan memang tidak bisa dipisahkan. Tidak dapat dipungkiri bahwa perempuan memiliki kekuatan atau magnet dalam membantu menjual dan mempromosikan produk yang akan diiklankan. Bila kita simak pembabakan Tamrin A Tomagola (1996) yang dikutip oleh Tinarbuko melalui sebuah artikel online (2011), terdapat lima citra perempuan dalam iklan, yaitu; citra pigura, pilar, peraduan, pinggan, dan pergaulan.

Dalam citra pigura, perempuan digambarkan sebagai sosok makhluk yang harus memikat. Oleh sebab itu, ia harus menonjolkan ciri-ciri biologis. Sedangkan (2) citra pilar, perempuan digambarkan sebagai pengurus utama keluarga. Pengertian budaya yang diadopsi yaitu lelaki dan perempuan sederajat, tapi dalam kodratnya berbeda. Dan (3) citra peraduan, beranggapan perempuan sebagai objek pemuasan laki-laki. Lain halnya dengan (4) citra pinggan, digambarkan bahwa bagaimana pun pendidikan ditekuni oleh perempuan dan sebesar apapun hasilnya, tetap kewajiban perempuan ialah berada di dapur. Dan terakhir (5) citra pergaulan, yaitu perempuan yang digambarkan sebagai seseorang yang digambarkan dipenuhi dengan kekhawatiran di dalam dirinya yang mana menyakinin bahwa ia tidak memikat atau tidak tampil menawan seshingga dapat diterima, wanita perlu untuk tampil secara memikat. Dari kelima citra tersebut memberikan opini 
bahwa perempuan yang telah dimanfaatkan bersamaan dengan meningkatnya profesionalisme di kalangan industri iklan. Sebab itulah, keberadaan perempuan didalam iklan.

Menggunakan sosok perempuan untuk melakukan sebuah promosi adalah sebuah hal yang lazim ditemui pada dunia periklanan, bahkan beberapa pekerja kreatif ialah keharusan. Perempuan dan iklan memang tidak bisa dipisahkan. Tidak dapat dipungkiri bahwa perempuan memiliki kekuatan dalam membantu menjual dan mempromosikan sebuah produk yang akan diiklankan. .

Sejalan dengan perkembangan usaha rokok yang cukup pesat, persaingan antar produsen rokok mulai terjadi. Beberapa perusahaan rokok berskala besar mencoba untuk bersaing dan berupaya untuk menjadi paling unggul melalui pemilihan kegiatan promosi yang tepat. Promosi periklanan rokok mulai berkembang seiring dengan berkembangnya teknologi mesin cetak oleh surat kabar di Indonesia. Jika dilihat ini adalah sebuah fenomena yang menarik ketika kita mengamati beberapa jenis media promosi rokok pada masa awal berkembangnya metode periklanan di Indonesia (Hafied, 2006).

\section{METODE PENELITIAN}

Teknik observasi akan dilakukan oleh peneliti dengan mengamati dan menganalisa gambar/foto yang peneliti dapatkan selama masa penelitian. Selain itu, Dokumentasi dilakukan dengan cara mengumpulkan berkas yang didapat. memalui internet, guna mendapatkan data yang sesuai dengan penelitian.

Pada penelitian ini, data yang sudah didapatkan peneliti melalui teknik-teknik tersebut akan peneliti analisis dengan menggunakan pendekatan semiotika menurut Roland Barthes. Setelah menentukan apa yang diteliti, dan pendekatan yang digunakan. Selanjutnya peneliti menngumpulkan data, dalam hal ini gambar/foto yang didapatkan di Internet.

\section{HASIL DAN PEMBAHASAN}

Peneliti akan menguraikan dan membahas hasil analisis pada iklan produk rokok pada tahun 19301950 di Indonesia dengan melihat pembentukan citra pada wanita yang terdapat di dalam iklan produk rokok. Peneliti secara khusus membagi menjadi 3 bagian, dengan jarak kurun waktu 10 tahun. Artinya iklan yang akan di analisis terdapat 3 buah gambar iklan produk rokok. Gambar iklan tersebut di analisis menggunakan Analisis Semiotika dengan Teori Roland Barthes yang membuat dua tahapan signifikasi semiotika yaitu : makna denotasi dan makna konotasi serta mitos

Makna denotasi berupa makna yang tersurat pada gambar atau makna awal yang timbul ketika seseorang melihat sebuah gambar atau foto. Sedangkan makna konotasi adalah makna yang terbentuk dari interaksi antara tanda-tanda dalam foto/gambar dengan perasaan atau emosi dan pengetahuan secara nilai-nilai kebudayaan dari pembaca. Pengertian mitos di sini tidaklah menunjuk pada mitologi dalam pengertian sehari-hari seperti halnya cerita-cerita tradisional melainkan sebuah cara pemaknaan. 
Produksi mitos dalam teks membantu pembaca untuk menggambarkan situasi sosial budaya, mungkin juga politik yang ada disekelilingnya atau makna ideologi yang terkandung di dalamnya. Untuk memudahkan menganalisis serta pembacaan tanda, gambar akan dibagi dengan beberapa bagian dengan tujuan untuk memudahkan membaca pemaknaan yang terdapat pada foto, sesuai dengan kebutuhan seperti foto pertama, kedua, dan ketiga (Suseno, 2003).

\section{A. Analisis Foto I}

Foto ini merupakan foto pertama pada iklan produk rokok yang terdapat di Indonesia, yaitu pada tahun 1930

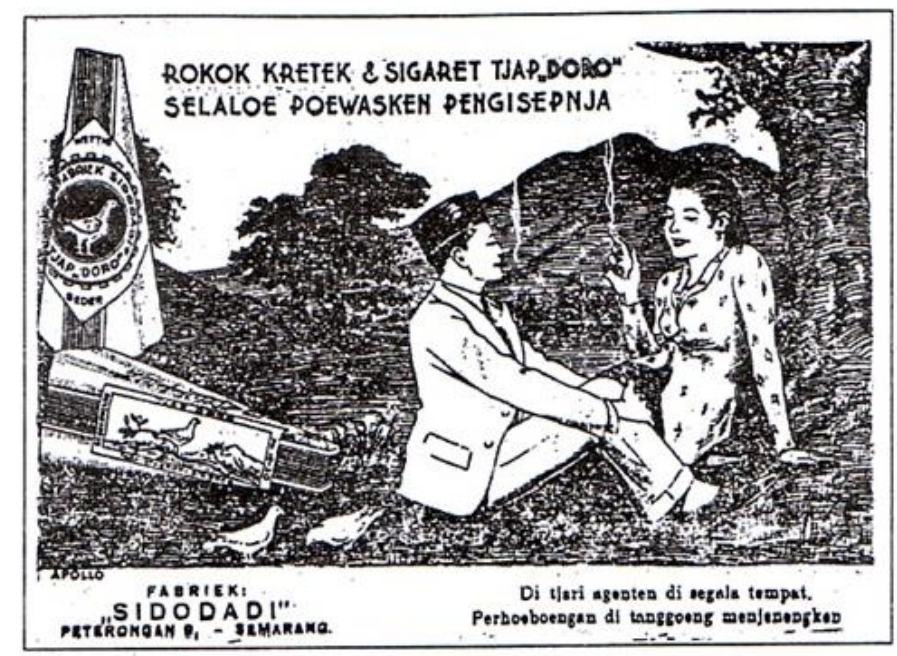

Gambar 1 : Foto Iklan Produk Rokok Pada Tahun 1930

Sumber : Iklan rokok di surat kabar Economic Blad, 3 Juni 1932

Pada foto pertama ini, terdapat pria dan wanita yang sedang duduk dengan pemandangan gunung dibelakang mereka. Serta terdapat hewan 2 ekor burung dan bungkus rokok berlogo ayam juga yang dapat dibaca melalui pemaknaan secara denotasi, konotasi dan mitos. Dan berikut pemaknaan pada foto pertama. Makna yang pertama adalah makna denotasi. Makna denotasi adalah makna yang tersurat pada foto atau gambar yang tertangkap kamera. Secara denotasi, peneliti memaknai foto ini sebagai foto yang mengambarkan suasana yang asri dengan perempuan dan laki-laki yang ada dengan latar belakang gunung, pohon-pohon besar disertai dengan gambar ayam yang ada di kotak rokok, dan juga 2 ekor ayam yang sedang memakan sesuatu.

Wanita dalam rokok ini menggunakan pakaian kebaya, dan laki-laki yang ada digambar memakai pakaian jas serta peci. Bisa dilihat dalam gambar tersebut rokok dalam keadaan menyala ditandai dengan asap yang mengepul. Serta tulisan dengan ejaan lama yang ada pada gambar. Terdapat juga, 2 tulisan yang ada yakni dibagian atas dan bawah. Pada bagian atas bertuliskan : ROKOK KRETEK \& SIGARET TJAP_DOBO SELALOE POESKEN PENGISAPNJA. 
Sedangkan pada bagian bawah pada bagian kiri : PABRIEK : "SIDODAD" I PETERONGAN, P -SEMARANG. Pada bagian kanan : Di tjari disegala tempat. Perboeboengan ditanggoeng mengjenengken.

Makna selanjutnya adalah makna konotasi. Makna konotasi adalah makna yang terbentuk dari interaksi antara tanda-tanda dalam foto/gambar dengan perasaan atau emosi dan pengetahuan secara nilai-nilai kebudayaan dari pembaca. Untuk memudahkan dalam membaca pemaknaan yang terdapat pada gambar maka peneliti, membagi foto seperti berikut : pertama latar belakang (background) gambar. Gambar diatas jika kita kaitkan dengan tahun 30-an, maka kondisi Indonesia saat itu belum banyak pembangunan yang ada. Sehingga pohon-pohon besar dapat dengan mudah ditemukan di Indonesia. Dikarenakan kondisi tersebut, Indonesia menjadi negara yang banyak memiliki pulau-pulau yang tersebar. Sehingga wajar saja, jika Indonesia juga dikenal sebagai negara agraris karena memiliki tanah yang subur.

Hal ini selaras dengan kondisi Indonesia yang berada pada kawasan tropis, dengan puluhan ribu pulau yang terbentang dari barat sampai ujung berung timur. Wajar saja jika Indonesia adalah salah satu negara yang banyak memiliki gunung yaitu sebanyak 125 .

Keberadaan gunung inilah yang membuat karekteristik tanah di Indonesia menjadi subur. Tidak heran, jika pembuat gambar tersebut menjadikan latar iklan produk rokok adalah sebuah pemandangan dengan gunung, pepohonan, serta tanaman-tanaman yang ada di pelataran di dalam gambar. Kemungkinan besar, alasan pemandangan dijadikan latar sebuah gambar pada iklan adalah untuk menginformasikan dan menjelaskan bahwa banyak sekali potensi alam yang di miliki oleh Negara Indonesia

Penulis juga membaca bahwa pembuat gambar ingin membuat suasana yang mendekat kepada alam. Berdasarkan hasil penelitian Roger S. Ulrich, PhD di Universitas Texas A\&M yaitu : Manusia memang diciptakan untuk mendekatkan diri dengan alam. Ketika mendekatkan diri dengan alam, tubuh kita akan serasa kembali ke 'rumah' yang asri dan tenteram.

Penulis juga mengambarkan bahwa, ada makna lain yang dibuat oleh pembuat gambar. Pemilihan latar belakang dengan pelataran gunung, pepohonan rindang serta rerumputan bukan tenpa alasan. Pertama, penulis memaknai bahwa kegiatan merokok identik dengan alam. Pada zaman itu kebanyakan masyarakat Indonesia mayoritas kebanyakan berladang dan bercocok tanam. Sehingga, rokok menjadi salah satu teman perjalanan yang dibawa. Tentu, ini adalah salah satu strategi dalam penjualan rokok yang memiliki pesan bahwa merokok adalah sebuah kegiatan yang biasa dilakukan pada sehari-hari.

Yang kedua yaitu sosok perempuan dalam gambar diatas, Penulis memaknai bahwa perempuan memiliki hubungan kepada sosok laki-laki tersebut, hal ini bukan tanpa alasan. Karena posisi duduk mereka yang terlihat akrab yang mendasari peneliti memaknai demikian. Peneliti beralasan bahwa, perempuan tersebut ialah seorang perempuan penghibur yang sedang menemani pejabat bersantai pada pelataran tempat yang asri. Dikarenakan kondisi Indonesia pada tahun 30an belum merdeka dan masih di kuasi oleh kolonial Belanda maka peneliti beranggapan perempuan tersebut adalah nyai atau wanita penghibur pada zaman dahulu. 
Sedangkan yang ketiga terlihat sosok laki-laki. Penulis melihat, bahwa pembuat gambar iklan rokok pada gambar ingin menyampakian pesan bahwa rokok ini bisa di nikmati hanya untuk kalangan kelas atas saja. Dan rokok ini adalah salah satu rokok yang biasa di konsusmsi oleh mereka kalangan elit kelas atas. Karena pada tahun 1930 Indonesia belum merdeka, kemungkinan konsumen rokok pada tahun itu berfokus kepada orang-orang petinggi. Jika kita kaitkan iklan produk rokok dalam gambar tersebut dengan kondisi Indonesia saat itu, maka kesimpulan yang kita dapat bahwa produksi rokok berfokus untuk menarik minat orang-orang dengan tingkat ekonomi yang berada, tetapi tidak dipungkiri juga bisa di nikmati oleh semua kalangan.

Yang keempat yaitu bungkus rokok. Pembungkus rokok, adalah kemasan yang digunakan untuk membungkus rokok agar rokok bisa terbungkus dengan rapih dan baik. Berbeda dengan kemasan rokok saat ini. Pada zaman dahulu, ini bisa kita lihat pada iklan rokok pada tahun 1930 bahwa kemasan pada saat itu hanya sebuah kotak segita dengan terdapat gambar ayam dan tulisan yang melingkar.

Yang kelima adalah hewan merpati.Peneliti memaknai bahwasannya pembuat gambar menampilkan 2 ekor burung adalah untuk melengkapi 2 orang yang sedang duduk di pelataran. Kreatifitas yang dimiliki pembuat gambar dalam iklan rokok pada tahun 1930 ini sangat detil. Peneliti melihat, ia ingin menyampaikan pesan cinta di dalamnya. Dibalik penggunaan lambang burung merpati ini bukannya tanpa alasan. Ada sebuah filosofi yang memiliki makna dari sepasang burung merpati ialah adalah burung yang tidak memiliki empedu, sehingga merpati tidak menyimpan kepahitan-kepahitan dalam hidupnya. Hal ini memiliki makna bahwa seseorang yang tidak memendam kepahitan dalam hidupnya, berarti dia adalah orang yang tidak menyimpan dendam terhadap siapapun.

Selain itu merpati adalah burung yang setia terhadap pasangannya. Berbeda dengan beberapa hewan ataupun burung yang berganti-ganti pasangan untuk berkembang biak, merpati adalah burung yang setia terhadap pasangannya. Pasangan burung merpati biasanya satu untuk seumur hidupnya. Itulah alasan mengapa merpati kerap dijadikan sebagai lambang kesetiaan dalam hubungan. Jika dikaitkan filosofi burung merpati dengan gambar iklan produk rokok, maka disimpulkan jenis rokok ini bukan hanya bisa di konsumsi saja. Tetapi juga memiliki rasa cinta disetiap hisapan batang rokok.

Keenam yaitu tulisan. Tulisan yang ada di iklan adalah bertujuan untuk menjelaskan merk, penjelasan barang/pruduk dan juga bisa sebagai komunikasi persuasif dengan tulisan yang menarik yang bertujuan untuk menarik banyak konsumen. Orang-orang yang bisa membaca tulisan tersebut ialah orang yang bisa membaca. 


\section{B. Analisis Foto II}

Foto ini muncul pada tahun 1938, dengan merk rokok Marikangen

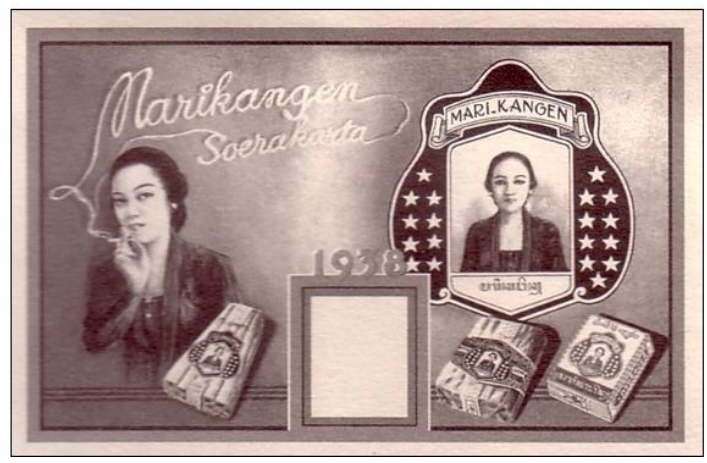

Gambar 2 : Iklan Produk Rokok Marikangen Tahun 1938

Sumber : Kalender produk rokok "Marikangen” 1938

Pada foto kedua ini, adalah foro pada tahun 1938, jaraknya 8 tahun jauh dengan rokok kretek yang pertama. Foto ini, hanya memuat gambar wanita saja. Dengan pose sedang merokok dan foto formal. Untuk mengetahui pemaknaan tanda yang terdapat. Berikut pemakanaanya. Yang pertama makna denotasi. Makna denotasi adalah makna yang tersurat pada foto atau gambar yang tertangkap kamera. Secara denotasi, peneliti memaknai foto ini, memuat gambar wanita dengan 2 pose/gaya yang berbeda. Serta mencantumkan tahun rilis produk, rokok Marikangen yaitu 1938. Di dalam gambar, terlihat juga tiga buah kota rokok dengan bungkus berbeda.

Perempuan pada rokok ini memakai pakaian kebaya sama seperti pada foto pertama. Bedanya, foto pertama menampakan gambar selutuh badan, sedangkan gambar ini hanya setengah badan saja. Perempuan ini juga menghias rambutnya dengan disanggul.

Pada bagian gambar kedua di logo rokok, terdapat gambar bintang dengan jumlah 20 buah bintang yaitu 10 pasang pada tiap sisinya. Di bagian bawah juga terdapat bingkai foto putih kosong tanpa gambar. Serta tulisan : Maringkangen Soerakarta, tulisan ini dengan huruf sambung diukir dari hisapan rokok pada perempuan.

Selanjutnya makna konotasi. Makna konotasi adalah makna yang terbentuk dari interaksi antara tanda-tanda dalam foto/gambar dengan perasaan atau emosi dan pengetahuan secara nilainilai kebudayaan dari pembaca. Untuk memudahkan dalam membaca pemaknaan yang terdapat pada gambar maka peneliti, membagi foto seperti berikut :

Pertama, perempuan pada gambar kedua berbeda dengan rokok digambar sebelumnya, pada bagian ini sangat jelas bahwa perempuan ini sebagai titik fokus utama sebuah iklan, karena ia termasuk didalam logo/lambang dari sebuah rokok. Penulis memaknai, bahwa tujuan dari pembuatan logo perempuan itu memiliki maksud dan tujuan tertentu. Jika kita lihat pada iklan sebelumnya, logo/lambang rokok hanya berupa simbol saja dengan mengangkat gambar hewan. 
Maka iklan ini, memiliki tujuan khusus, pembuat gambar langsung menampilkan sosok perempuan didalam logo/lambang dari sebuah iklan rokok merk mari kangen. Penulis melihat, ini adalah salah satu strategi menyaring konsumen rokok perempuan secara masif. Dengan menampilkan langsung sosok perempuan, artinya kemungkinan besar bahwa perempuan yang merokok adalah sebuah hal yang lumrah dan biasa. Bahkan dalam kurun waktu 8 tahun. Produsen rokok, sudah bisa membuat iklan dengan terang-terangan perempuan sebagai ikon dalam merk sebuah rokok.

Berikutnya adalah tulisan. Tulisan di dalam iklan diatas adalah sebuah penjelasan yang tersurat untuk menginformasikan kepada konsumen. Tulisan yang ada di dalam rokok ini ada beberapa yaitu : Mari kangen, yang ditulis dengan huruf tegak bersambung dengan Soekarta dan huruf balok, dan 1938 adalah tahun produksi rokok, serta huruf sanskerta.

Mari kangen dengan tulisan tegak bersambung ini, dibentuk dari kepulan asap rokok yang berasal dari hisapan rokok oleh perempuan yang sedang mengkonsumsi rokok. Ini adalah sebuah kreatifitas yang dibuat oleh pembuat iklan, karena tulisan itu juga bersambung pada tulisan Soekarta yaitu kota tempat produksinya rokok ini. sedangkan tulisan mari kangen disebelahnya ditulis dengan huruf balok dan ditambah dengan titik (.) sebagai spasi. Untuk tulisan tegak bersambung sendiri, penulis belum menemukan sejarah pasti, huruf ini sudah ada di Indonesia.

Pemberian nama mari kangen sebagai merk, tentu memiliki alasan tersendiri. Penulis mengartikan $:$ Mari $=$ ajakan. Kangen $=$ ungkapan rindu. Jadi, penulis menyimpulkan bahwa merk ini diberi nama mari kangen bertujuan untuk mencitrakan : setiap orang yang mengkonsumsi rokok atau mencicipi rokok ini akan merasakan kerinduan pada sesuatu.

Berikutnya adalah kemasan rokok.Pada gambar ini, kemasan rokok memiliki 3 jenis bentuk yang berbeda tetapi tetap dengan logo yang sama. Ini menandakan bahwa produksi dari rokok mari kangen, banyak memiliki varian yang berbeda. Dan sudah memiliki pasar konsumen yang cukup luas dengan startegi pemasaran yang tepat. Ini selaras pada pemakaian bintang di dalam gambar produk, yang memaknai bahwa rokok ini adalah rokok yang memiliki kualitas yang terbaik. Untuk kemasan pertama, berbentuk seperti kerucut dengan bagian atas lebih kecil pada bawah, sedangkan 2 kemasan yang lainnya berbentuk kotak. Dengan kota yang pertama lebih besar.

\section{Analisis Foto III}

Foto ini merupakan iklan pada tahun 1950 yang beredar di Indonesia, dengan rokok jenis kretek merk Putri Solo. 


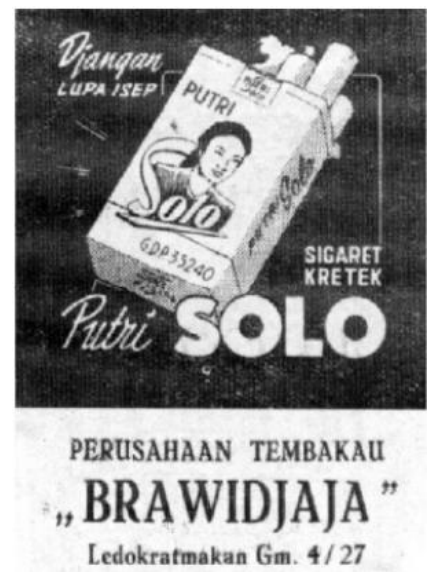

Gambar 3.9 : Iklan Produk Rokok Pada Tahun 1950 dengan Merk Putri Solo Sumber : Iklan Rokok Putri Solo di Dok. 200 ${ }^{\text {th }}$ Yogya

Pada foto ketiga yang dimuat pada tahun 1950 dengan merk Putri Solo. Berbeda dengan kedua iklan diatas, ikalan rokok ini lebih banyak tulisan Untuk mengetahui pemaknaan tanda yang terdapat. Berikut pemakanaanya.

Pertama makna denotasi. Foto yang dimuat pada tahun 1950 dengan merk Putri Solo. Memiliki perberdaan dengan kedua iklan rokok diatas, karena iklan rokok ini lebih banyak tulisan, mulai dari tulisan diatas yaitu : Djangan lupa isep, dan bagian tengah : SIGARET KRETEK, Putri Solo, serta bagian bawah : PERUSAHAAN TEMBAKAU „, BRAWIDJAJA” Ledokratmakan Gm. 4/27. Seperti pada iklan rokok sebelumnya, rokok tahun 1950 ini juga menghadirkan gambar seorang wanita sebagai ikon gambar dengan pose formal dan rambut dibagian bawah terurai. Pada bungkus rokokini memuat tulisan Putri Solo sebanyak 4 kali, disetiap sisi bungkus rokok. Dengan yang paling besar pada bagian depan. Dibagian bawah juga terdapat tulisan : GDP 35420 .

Yang kedua makna konotasi. Makna konotasi adalah makna yang terbentuk dari interaksi antara tanda-tanda dalam foto/gambar dengan perasaan atau emosi dan pengetahuan secara nilainilai kebudayaan dari pembaca. Untuk memudahkan dalam membaca pemaknaan yang terdapat pada gambar maka peneliti, membagi foto seperti berikut :

Sosok Perempuan. Sosok perempuan pada gambar iklan rokok tahun 1950 ini hanya menampilkan setengah badan saja dengan bahu yang terlihat tegap dan tegas. Berbeda dengan gambar sebelumnya diatas. Perempuan pada iklan pertama dan kedua di dalam gambar dibuat sedang melakukan aktifitas merokok.

Penampilan wanita ini juga sangat sederhana. Rambut dibagian atas dikucir dan terurai kebawah. Jika kita amati foto ini banyak sekali menuliskan kata Putri Solo. Penulis melihat ada 2 kemungkinan yang terkandung di dalam peenggunakan kata "Putri Solo". Pertama, pembuat gambar mengartikan bahwa perempuan yang ada di dalam rokok ini ialah sosok perempuan yang mandiri, dilihat dari kata Solo. Solo berarti tunggal (melakukan sesuatu dengan melakukan seorang diri). 
Iklan rokok ini diterbitkan pada tahun 1950, yaitu 10 tahun setelah kemerdekaan negara Indonesia. Jika kita kaitkan pada gambar, kemungkinan pembuat gambar ingin menggambarkan perempuan yang cerdas dan mandiri yang dimuat dari gambar iklan rokok ini. Kedua, penulis berfikir bahwa pembuat gambar ingin menyampaikan pesan yaitu perempuan yang ada di gambar iklan rokok, ialah perempuan dari kota Solo.

Yang kedua adalah bungkus rokok. Bungkus rokok pada merk Putri Solo ini hanya memiliki satu jenis bungkus rokok saja, tidak seperti bungkus rokok pada merk mari kangen. Jika kita lihat dengan menggunakan panca indera dalam memaknai bungkus rokok ini. pembuat gambar memuat bungkus rokok dengan mengeluarkan 3 batang rokok dari di dalam bungkusnya. Artinya rokok yang disusun di dalam bungkus tersebut bisa langsung dengan mudah dikeluarkan, hanya dengan sedikit robekan pada pembungkus. Peneliti melihat bahwa mengeluarkan rokok seperti di gambar adalah salah satu strategi dalam memasarkan produk rokok (Tineke, 2007).

Selain itu juga, di setiap sisi rokok terdapat merk rokok yaitu Putri Solo dengan berbagai jenis bentuk tulisan. Tentu ada alasan tersendiri mengapa kota Solo menjadi merk dari rokok ini. karena rokok ini dibuat di kota Yogyakarta dengan perusahaan tembakau Brawidjaja sebagai pelopornya.

Berikutnya adalah tulisan yang ada pada gambar. Iklan tahun 1950 ini banyak memuat beberapa tulisan, disetiap sisi pada etiket iklan rokok merk Putri Solo, yaitu : Djangan LUPA ISEP, beberapa penggulan kata Putri SOLO, SIGARET KRETEK, PERUSAHAAN TEMBAKAU „BRAWIDJAJA” Ledokratmakan Gm. 4/27.

Pertama, Djangan LUPA ISEP kata ini terdapat dibagian pojok kiri atas. Tulisan ini masih menggunakan ejaan Van Ophuijsen, Menurut KBBI makna dari kata Jangan adalah kata yang menyatakan melarang, berarti tidak boleh; hendaknya tidak usah. Dan kata Lupa berarti tidak dalam pikiran; tidak ingat; tidak sadar. Sedangakan hisap ialah memasukkan (menarik ke dalam) dengan kekuatan hawa; menarik masuk hingga meresap; menghirup; menyedot.

Ejaan Van Ophuijsen sekarang diganti dengan EYD (Ejaan yang Disempurnakan) maka pembacaan dari kata tersebut adalah : Jangan lupa hisap. Jika kita kaitkan pada sejarah rokok yang sudah diterangkan di awal pemabahsan Bab I, maka makna hisap disini memiliki arti rokok bisa menyembuhkan penyakit. Karena jenis rokok ini adalah kretek, yaitu pada awal munculnya menghirup/menghisap rokok kretek berfungsi sebagai obat.

Namun penulis juga melihat makna lain dari tulisan : Jangan lupa hisap ini sebagai seruan untuk mengkonsumsi rokok Putri Solo. seruan/ajakan biasa ditemukan dalam iklan-iklan yang memasarkan produk dagangan agar menarik konsumen.

Kedua, Putri Solo kata ini muncul sebanyak 4 kali. Ini menjadi sebuah penekanan pada merk dari rokok tersebut. Beberapa alasan penggunaan kata Putri Solo, dikarenakan hadir sosok perempuan sendirian di foto dan kemungkinan produsen rokok ingin menampilkan sosok perempuan dari Kota Solo yang dikenal anggun dan cantik untuk menjadi ikon produk.

Tulisan Putri Solo juga dimuat dengan beberapa bentuk tulisan. Ada yang berbentuk : Putri SOLO. Kata Putri disini, dibuat dengan tulisan huruf tegak bersambung. Dan kata SOLO dengan 
huruf besar kapital. Selain itu, ada bentuk tulisan yang lain yaitu PUTRI Solo. Penulis berpendapat bahwa penampilan variasi dalam penulisan rokok yang terdapat didalam bungkus rokok selain menjelaskan merk, juga sebagai salah satu ajang promosi Kota Solo. Jika pada bagian atas penulis menjelaskan, bahwa rokok ini ingin menyampaikan bahwa perempuan Kota Solo terkenal dengan kecantikan dan anggun. Maka dalam pembacaan tulisan ini penulis memaknai pembuat gambar ingin memberikan pesan bahwa bukan hanya Kota Yogyakarta saja yang memiliki kerjaan kraton dengan perempuan cantik di dalamnya tetapi juga Kota Solo . Artinya, jika secara seksama diperhatikan dan dikaji dengan teliti. Maka pada iklan rokok merk Putri Solo ini ada sebuah pesan tersirat dibalik merk tersebut. ada 2 kemungkinan yang penulis simpul bahwa : 1). Pemilik rokok ini berasal dari Kota Solo, sehingga ingin mempromosikan bahwa Kota Solo juga memiliki rokok, dan 2). Pemilik rokok ingin menampilkan sebuah pesan lewat kemasannya bahwa perempuan di Kota Solo mayoritas perempuan sudah terbiasa merokok, sehingga merk Putri Solo menjadi ikon dari rokok tersebut.

Ketiga, PERUSAHAAN TEMBAKAU ,BRAWIDJAJA” Ledokratmakan Gm. 4/27. Tulisan ini dibuat dalam ukuran yang cukup besar pada bagian bawah. Brawijdaja adalah nama dari perusahaan tembakau yang memproduksi rokok merk Putri Solo, sedangkan Ledokratmakan Gm adalah nama sebuah jalan di kota Yogjakarta.

Keempat, SIGARET KRETEK ini adalah jenis rokok. Sigaret berarti rokok sedangkan kretek adalah bunyi yang dimunculkan akibat pembakaran batang rokok yang sedang dihisap. Sigaret rokok sendiri terdiri dari dua, yaitu : SKT (sigaret kretek tangan) dan SKM (sigaret kretek mesin).

Selain itu terdapat tulisan GDP35420, tulisan ini peneliti makna sebagai no produk dari rokok Perusahaan Tembakau Brawidjaja. Jika saat ini ada badan yang bernaung untuk mengawasi sebuah produk pada di daerah adanya Dinkes atau Dinas Kesehatan. Sedangkan untuk produk dengan sekala besar yang di pasarkan di masyarakat yaitu BPOM atau Badan Pengawas Obat dan Makanan. Untuk itu peneliti beranggapan bahwa GDP35420 adalah sebuah kode produk. Alasan ini, tentu berujuk pada rokok sigaretini sudah di produksi secara besar (Alim, 2000). Bukan sebagai produk rumahan lagi, dengan nama perusahaan Tembakau Tembakau Brawidjaja.

\section{Citra yang Terbentuk}

Setelah menguraikan dan membahas hasil analisis pada iklan produk rokok pada tahun1930-1950 di Indonesia dengan melihat pembentukan citra pada wanita yang terdapat di dalam iklan produk rokok, Maka pembentukan citra pada perempuan sebagai berikut :

Analisi Foto I (1930), yaitu gambar perempuan dalam gambar tersebut adalah perempuan

yang digambarkan dengan citra : (1) citra pigura, perempuan digambarkan sebagai sosok makhluk yang harus memikat, (2) citra peraduan, berangapan perempuan sebagai obyek pemuasan bagi laki-laki. (3) citra pergaulan, yaitu wanita perlu tampil memikat secara fisik. 
Hal ini selaras dengan pemakanaan yang penulis baca pada iklan produk rokok merk sidodadi, dimana perempuan digambarkan sosok perempuan yang memikat dengan ditandai posisi duduk yang berdekatan dan sorotan mata yang tajam serta garis senyum yang dilemparkan kepada lai-laki.

Tidak hanya itu, respon yang muncul dari pihak laki-laki pun ditandai dengan posisi kaki mereka yang berdekatan sehingga situasi seperti berhasil membentukan citra bahwa perempuan tersebut mencitrakan sebagai citra pigura.

Berdasarkan paparan diatas juga, penulis memaknai bahwa perempuan tersebut ialah wanita penghibur atau biasa yang disebut dengan nyai pada kalangan Kolonial Belanda, alasan ini karena pada tahun 30-an Indonesia dalam keadaan belum merdeka, kondisi perekonomian di zaman itu yang cukup sulit yang mengakibatkan menjadi seorang wanita penghibur adalah sebuah pilihan, perbandingan laki-laki yang banyak ketimbang perempuan, dan juga ditandai dengan kedekatan perempuan dan laki-laki yang berada di dalam gambar. Alasan-alasan ini juga yang membuat penulis memaknai bahwa perempuan tersebut memiliki citra paraduan dan citra pergaulan.

Analisis selanjutnya yaitu Analisis Foto II (1938). Berbeda dengan iklan sebelumnya, iklan rokok merk mari kangen ini hanya menampilkan sosok perempuan saja. Sehingga perempuan di dalam gambar ini adalah perempuan yang digambarkan dengan citra : (1) citra pigura, perempuan digambarkan sebagai sosok makhluk yang harus memikat. Citra ini digambarkan dengan menonjolkan ciri-ciri biologis. Seperti yang dijabarkan pada analisis di atas, perempuan ini dibuat dengan 2 pose gaya yang berbeda. Jika kita pahami lagi, kemajuan dalam penggunakan perempuan di dalam iklan cukup meningkat. Dilihat dari rokok merk mari kangen yang hanya menampilkan sosok perempuan saja. Pembuat gambar juga membuat gambar perempuan dengan sangat jelas, bentuk fisik dari perempuan ini. Sehingga, citra pigura yakni perempuan digambarkan sebagai sosok makhluk yang harus memikat ditandai dengan ciri-ciri biologis yang tergambar sangat jelas tepat untuk pemakanaan citra pada iklan merk mari kangen.

Sedangkan pada foto III (1950) penulis melihat iklan rokok ini berbeda dengan iklan-iklan sebelumnya, jika kedua iklan diatas perempuan sedang merokok maka berbeda dengan iklan produk rokok merk brawidjadja ini. Pada iklan ini, perempuan terletak pada bagian tengah di latar bungkus rokok dengan tulisan Putri Solo yang besar. Sehingga perempuan di dalam gambar ini adalah perempuan yang digambarkan dengan citra : (1) citra pigura, perempuan digambarkan sebagai sosok makhluk yang harus memikat. Citra ini digambarkan dengan menonjolkan ciri-ciri biologis.

Sama dengan penjabaran di atas bahwa, hadirnya sosok perempuan sendirian di foto dan kemungkinan produsen rokok ingin menampilkan sosok perempuan dari Kota Solo yang dikenal anggun dan cantik untuk menjadi ikon produk. Serta kemungkinan-kemungkinan yang penulis jabaralan pada iklan produk rokok. 


\section{KESIMPULAN}

Hasil yang diteliti terhadap 3 foto iklan rokok, peneliti menyimpulkan bahwa pembentukan citra pada iklan rokok tersebut memiliki 3 Citra dari 5 citra yang ada yaitu : (1) citra pigura, (2) citra peraduan, (3) citra pergaulan. Tetapi dari ketiga citra tersebut yang lebih dominan ialah citra pigura, dimana semua perempuan yang ada di dalam iklan dibentuk sebagai perempuan yang memikat. Bisa dilihat dari gambar pada berbagai rokok dengan pose atau gaya yang demikian di buat oleh pembuat gambar, serta pakaian dan aksesoris pendukung yang dipakai oleh perempuan dalam gambar iklan membuat makin seolah memikat. Tentu alasan dari pembuatan seperti itu tidak lain agar penjual rokok bisa memasarkan produknya dengan jangkauan yang luas. Yaitu bukan hanya berfokus pada laki-laki saja tetapi juga pada perempuan juga bisa dijangkau oleh penjual rokok. Selain itu juga, banyak terdapat pesan yang terkandung di dalam iklan rokok tersebut. 
Reza Aprianti, Ahmad Muhaimin, Sisca Shamannia, Citra Perempuan Pada Produk Rokok di Era Tahun 1930-1950, JSSP, Vol. 2, No. 2, Desember 2018

\section{DAFTAR PUSTAKA}

A Soeseno. (2003). Memelihara dan Bertenak Burung Merpati, Jakarta : PT. Penebar Swadaya Cangara, Hafied. (2006). Pengantar ilmu Komunikasi, Jakarta : PT. Grafindo.

Hellwing, Tineke. (2007). Citra Kaum Perempuan di Hindia Belanda, Jakarta : Yayasan Obor Indonesia.

Hendriana, Evelyn. (2015). Ekonomi Kreatif: Rencana Pengembangan Periklanan Nasional 2015 2019, Jakarta : PT. Republik Revolusi.

Kurniawan. (2001). Semiotik Roland Barthes, Magelang: Indonesia Tera.

Mukkarom. (2014). Sejarah Islam Indonesia 1, Surabaya : Government of Indonesia

Roem, Topatimasang, Puthut Ea. (2010). Kretek: Kajian Ekonomi \& Budaya 4 Kota, Indonesia Berdikari \& Spasi Media

Sobur, Alex. (2004). Semiotika Komunikasi. Bandung : PT. Remaja Rosdakarya

Sugiyono. (2006). Metodologi Penelitian Kualitatif dan Kuantitaif, Bandung: Alfabeta,

Tanzeh, Ahmad. (2011). Metodelogi Penelitian Praktis Yogyakarta: Teras

Verdiansyah. (2004). Pengantar Ilmu Komunikasi, UI : Ghalia Indonesia

Winarno, B. (2008). Rumah Iklan: Upaya Matari Menjadikan Periklanan Indonesia Tuan Rumah di Negeri Sendiri, Jakarta : Kompas Media Nusantara

Zaman, Moh Alim. (2000). 100 Tahun Mode Indonesia 1901-2000, , Meutiara Cipta Sarana Dewa: Dewan Pimpinan Pusat (DPP) Ikatan Penata Busana Indonesia 'Kartini' 